\title{
Exploration for limestone deposit at Onigbedu, South-Western Nigeria
}

\section{Sledenje nahajališč apnenca pri Onigbeduju v jugozahodni Nigeriji}

\author{
Kayode F. Oyedele, Sunday Oladele*, Charles A. Emakpor \\ University of Lagos, Department of Geosciences, Lagos, Nigeria \\ *soladele@unilag.edu.ng
}

\begin{abstract}
The Onigbedu limestone deposit was investigated using the aeromagnetic data, resistivity soundings and borings with the aim of characterizing the limestone deposit and estimating its reserves. The subsurface structural features and depth to basement were identified with the analysis of aeromagnetic data. Twenty nine boreholes were drilled for subsurface appraisal and correlation of the limestone deposit. Eighty nine Vertical Electrical Sounding (VES) were acquired using the Schlumberger array. The results showed NE-SW trending lineaments that segmented the limestone. Depth to basement varied from $144.2 \mathrm{~m}$ to $1090 \mathrm{~m}$. The VES results showed four to six layers indicating the topsoil (7-315 $\Omega \mathrm{m})$, clay (2-25 $\Omega \mathrm{m})$, shale $(6-31 \Omega \mathrm{m})$, limestone (20-223 $\Omega \mathrm{m})$, sandstone $(>200 \Omega \mathrm{m})$ and sandy materials. The VES results correlated well with the lithological unit delineated from the borehole. The overburden thickness ranged from $3.3 \mathrm{~m}$ to $28 \mathrm{~m}$, while the limestone thickness varies between $18.1 \mathrm{~m}$ and $48.3 \mathrm{~m}$. The limestone reserve was estimated at $1.9 \times$ $10^{9} \mathrm{t}$. This study concluded that the study area had vast occurrence of the limestone deposits, which would be of economic importance, if exploited.
\end{abstract}

Key words: limestone, aeromagnetic, resistivity, boring, tonnage, overburden

\section{Izvleček}

Onigbedujsko nahajališče apnenca so raziskovali z uporabo aeromagnetnih podatkov, upornostnih meritev in globinskega vrtanja z namenom opredeliti nahajališče in izračunati zaloge. Značilnosti zgradbe in globino do podlage so določili z analizo aeromagnetnih podatkov. Za opredelitev razsežnosti apnenčevega nahajališča v globini so izvrtali devetindvajset vrtin. Izmerili so devetinosemdeset vertikalnih električnih sond (VES), in sicer s Schlumbergerjevim razporedom elektrod. Rezultati nakazujejo v apnencu lineamentne struktiure smeri NE - SW. Globina do podlage znaša od $144.2 \mathrm{~m}$ do $1090 \mathrm{~m}$. Iz upornostnih meritev je mogoče razlikovati šest plasti: površinska tla (7-315 $\Omega \mathrm{m})$, glino (2-25 $\Omega \mathrm{m})$, laporovec (6-31 $\Omega \mathrm{m})$, apnenec $(20-223 \Omega \mathrm{m})$, peščenjak $(>200 \Omega \mathrm{m})$ in peščene materiale. Te določitve se lepo ujemajo z litološkimi enotami, ki so jih ugotovili v vrtinah. Debelina površinskegaa pokrova se giblje med 3,3 $\mathrm{m}$ in $28 \mathrm{~m}$, debelina apnenca pa med 18,1 m in $48,3 \mathrm{~m}$. Zaloge apnenca so ocenili na $1,9 \times 10^{9}$ ton. Iz raziskave sklepajo, da premore nahajališče $\mathrm{v}$ primeru potrebe dovolj apnenca za gospodarno izkoriščanje.

Ključne besede: apnenec, aeromagnetna metoda, upornost, zaloge, površinski pokrov 


\section{Introduction}

The occurrence of limestone has been reported at Onigbedu, south-western Nigeria [1]. Despite the report, the limestone deposit remains largely uncharacterized. Limestone is a carbonated sedimentary rock composed mainly of calcium carbonate $\left(\mathrm{CaCO}_{3}\right)$, usually precipitated either by the action of organisms or directly as the result of organic processes. The majority of limestone occurrence is biochemical limestone, which is usually formed from wave-broken fragments of algae, corals and shells [2]. Limestone can be formed in several ways and in different geological situations, usually in the sea [3]. They may be deposited in deep water far from land, in shallow water near the shore or somewhere in between. Some limestone are almost pure carbonate, while others contain substantial proportions of other materials, most commonly sand, clay (mud or shale) and chert, which may also concentrate in distinct beds (most commonly, beds of shale) interbedded with the limestone [1]. Limestone may also contain small amount of metallic materials such as marcasite or galena [4]. However, the composition of limestone has made it valuable in making a variety of products that are essential to the modern way of life especially in cement production, which serves as the major raw material. Limestone terrains often develop karst topography characterized by a suite of landforms comprising springs, dolines, caves, collapsed sinkholes and carbonate depositional landforms [5]. The geophysical methods are very useful for limestone investigation because of the intrinsic heterogeneity of the medium $[6,7]$. The high contrast in resistivity values between carbonate rock, clayey and sandy materials favours the use of electrical resistivity method for determining the boundary between these Earth materials [8]. In this study, the geophysical and geological (boring) methods were employed to investigate the Onigbedu limestone deposit. These methods have been used in the reserve estimation of mineral deposits in Nigeria [9].

\section{Location And Geology Of The Study Area}

Onigbedu is located within the Ewekoro local government of Ogun state. The area lies between longitudes $\mathrm{E}_{003}{ }^{\circ} 07.83^{\prime}$ and $\mathrm{E} 003^{\circ}$ 07.64', and latitudes $\mathrm{N}^{\prime} 6^{\circ}$ 58.03' and $\mathrm{N}^{\prime} 6^{\circ}$ 57.32 ' (Figure 1). The area has considerable relief and thick vegetation typical of tropical rain forest setting. The area has a tropical climate made up of two seasons - wet season (April to October) and dry season (November to March). The geology of Onigbedu is situated in the context of Benin basin in south-western Nigeria (Figure 1). The Benin basin was initiated during the Mesozoic in response to the separation of the African-South American landmasses and the subsequent opening of the Atlantic. The available stratigraphic evidence [1] suggests that deposition was initiated in fault controlled depression on a crystalline Basement Complex. The evidence [1] also indicated that the rift generated basement subsidence during the Lower Cretaceous resulted in the deposition of a very thick sequence of continental sediments (conglomerates) and pebbly sands. The pre drifts and post drift arenaceous deposits are preserved in Afowo and Ise, according to Omatosola and Adegoke [1]. The study revealed that sediment deposition began in the south-western part of Nigeria during the Maastrichtian, with the deposition of the Abeokuta Formation sediments as the oldest sediment in the basin. The formation consists mainly of sands, shaleclays and calcareous parts. They are partly marine, partly brackish/fresh water in origin and lies unconformably on the basement Complex [10]. The sedimentation continued during the Tertiary with the deposition of the Ewekoro and Akinbo Formation during the Paleocene. The Ewekoro Formation consists mainly of limestone, while the succeeding Akinbo Formation is composed of grayish- green thickly laminated and highly fossiliferous shale. During the Eocene, there was the deposition of a sequence of marine shale and clay known as the Oshosun Formation. It is overlain by a sequence of coarse sandy deltaic and continental beds of sands, clays and shales of the Ilaro Formation. Capping the sedimentary succession in the area is a thin bed consisting of a series of 


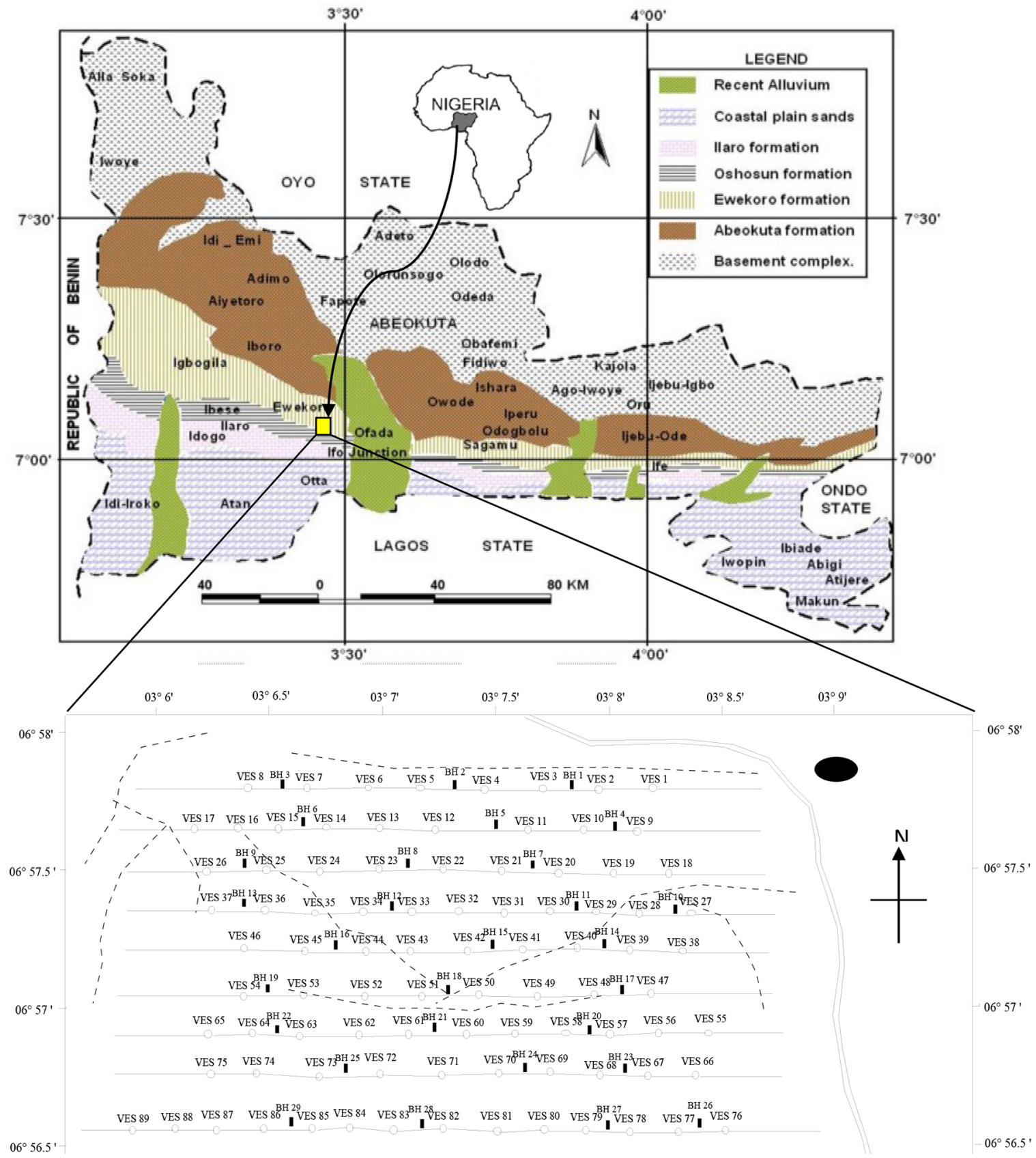

Figure 1: Location, Geological Setting and Base Map of the Study Area. Dashed lines Represent Footpaths.

highly fossiliferous greyish-green, sandy-clayey sandstones with calcareous parts known as the Ameki Formation. Whenever it occurs, it is found lying directly on the Oshosun Formation. However, the sedimentary succession terminates with the Quaternary to recent alluvial deposit along the river valleys.

\section{Materials and Methods}

\section{Materials}

Aeromagnetic data, borehole logs and resistivity sounding data were employed for this study. The aeromagnetic data supplied by the Nigeria Geological Survey Agency (NGSA), was acquired using Proton Procession Magnetometer at a terrain clearance of $80 \mathrm{~m}$ and flight spacing 
of $500 \mathrm{~m}$ in NW-SE direction. The tie lines were flown at $2 \mathrm{~km}$ spacing in NW-SE direction. Regional gradient was removed from the data using the International Geomagnetic Reference Field (IGRF) 2005. Twenty nine (29) boreholes lithologic logs from well drilled with shell and Auger drilling machine were employed for the lithological studies. Eighty nine (89) resistivity sounding data acquired in grid pattern were employed in probing the subsurface.

\section{Methods}

Aeromagnetic data processing: Aeromagnetic data analysis was carried out on the platform of Geosoft package software version 6.3. The reduction to the equator (RTE) approach of Martin [11] was employed to remove the asymmetry and declination effect from the aeromagnetic data. The regional residual separation of data was accomplished by subtracting the data upward and continued to $100 \mathrm{~m}$ from the original data. The first total horizontal derivative of the residual data as described by Cordell and Grauch [12] was computed to image the regional structures. Source Parameter Imaging approach of Thurston and Smith [13] was employed to estimate the depth to magnetic basement, hence the thickness of the sedimentary package.

\section{Borehole Drilling}

The boreholes were drilled with a shell and Auger drilling at selected locations (Figure 1). Dango rotary core drilling rig and diamond drilling bit of $76 \mathrm{~mm}$ diameter was used for the boring. Cross sections across the boreholes were drawn to correlate the various subsurface layers.

\section{Vertical Electrical Sounding (VES)}

The VES were acquired in grid pattern (Figure 1) using Schlumberger electrode array. The ABEM Terrameter SAS 1000C model was employed for data acquisition at maximum electrode spacing of 300-400 m. The partial curve matching technique of the Zohdy [14] was employed in interpretation of the VES data. The interpretations were refined using computer iteration. Geoelectric sections in E-W, N-S and NE-SW directions were constructed to obtain the thickness and true resistivity of the subsurface layers. Maps of identified limestone and overburden thickness were constructed.

\section{Results and Discussion}

\section{Aeromagnetic anomaly}

Qualitatively, the aeromagnetic maps (Figure 2) showed anomalies characterized by both low and high intensity. The high magnetic intensity values are located at the south-western part of the study area, while the low magnetic intensity values are shown at the north-eastern part of the area. The Residual magnetic data (Figure 3) shows that the study area was characterized by high and low intensity. The low magnetic amplitude was interpreted to be indicative of area of shallow basement. The high amplitude of anomalies was interpreted to be an area of deep basement.

\section{Structure and Depth to Basement}

The first horizontal derivative map (Figure 4) shows a series of lineaments trending towards the NE-SW direction. These lineaments may represent faults and fractures that segmented the basement into block pattern. The NE-SW direction of the structural elements is consistent with the trend of the continental extension of the oceanic transform faults [15]. The propagation of these structural elements into the overlying sedimentary section might have resulted in the segmentation of the limestone deposits. Depth to magnetic basement (Figure 5) provides information on the configuration of the basement. The depth to the magnetic basement ranges from $144 \mathrm{~m}$ to $1090 \mathrm{~m}$ (Figure 5). These values also mirror variations in the thickness of sedimentary package.

\section{Lithologic units}

The borehole sections showing the thicknesses and correlation of lithologic units in the study area are shown in Figure 6a and 6b. Six lithologic units were identified: the sandy clay, clay, shale, limestone, sandstone and sand. The sandy clay, clay and shale overlie the limestone and form an overburden which varies between $5.6 \mathrm{~m}$ and $23.3 \mathrm{~m}$ in thickness. 


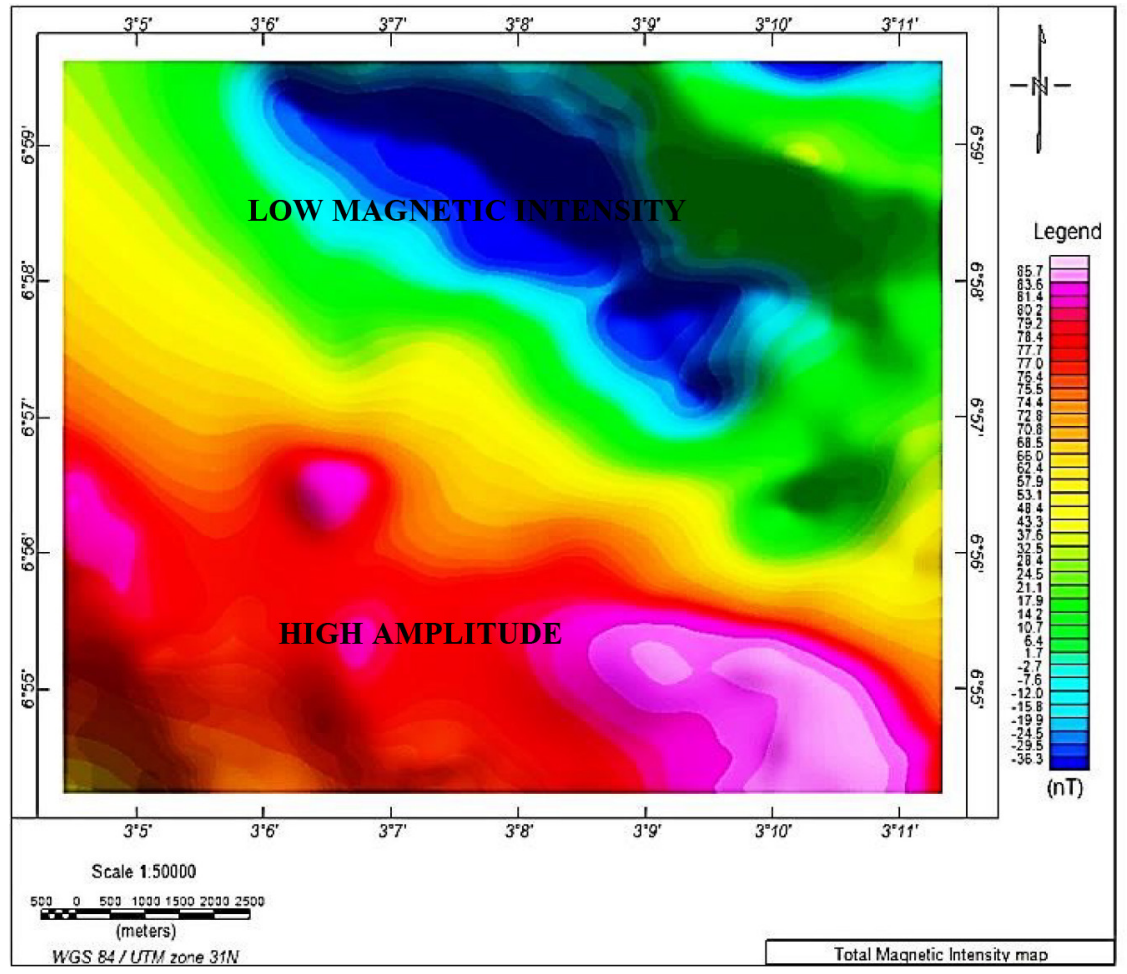

Figure 2: Total Magnetic Intensity Map (TMI) Aeromagnetic Data

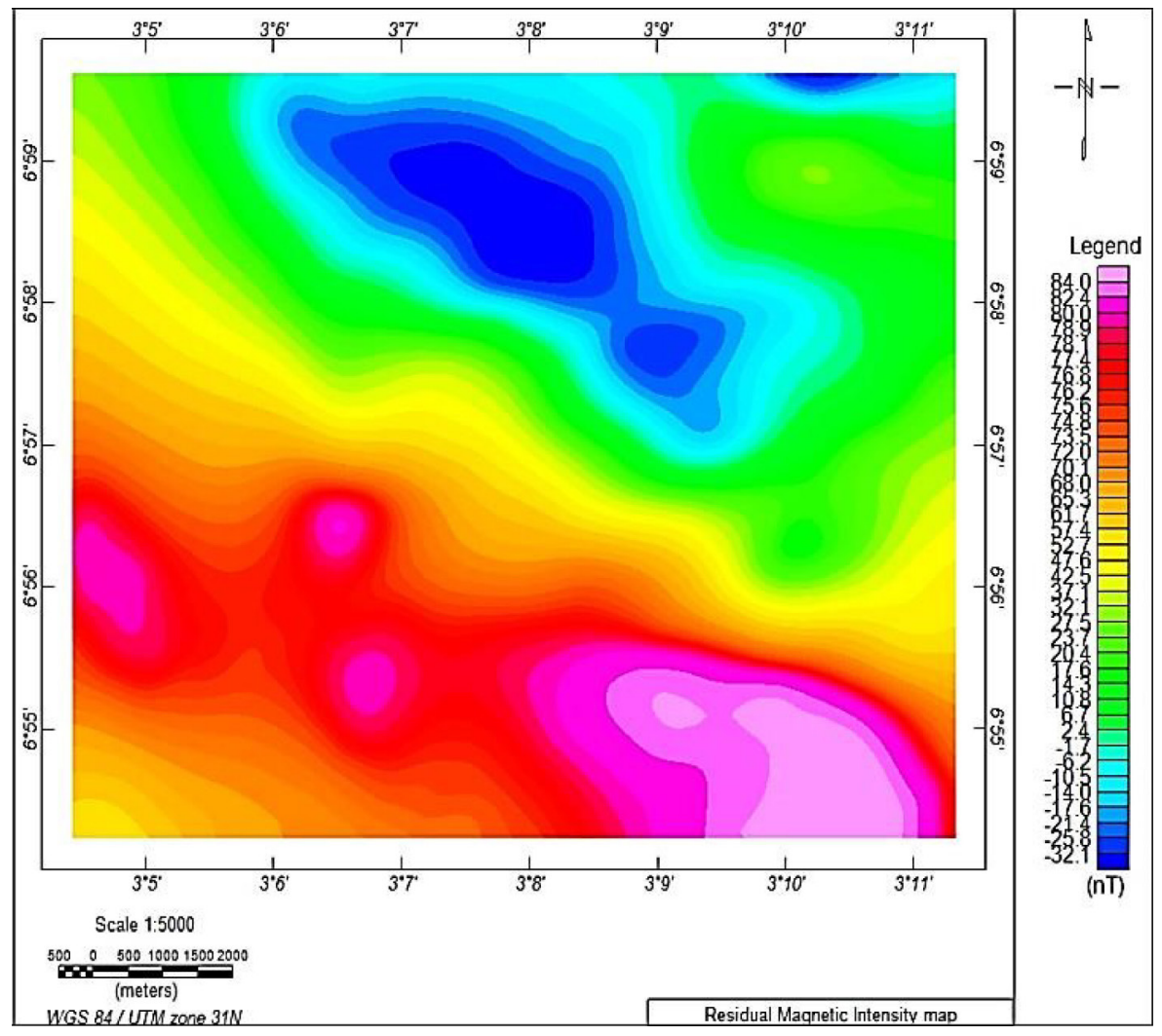

Figure 3: Residual of Total Magnetic Intensity (TMI) Aeromagnetic Data 


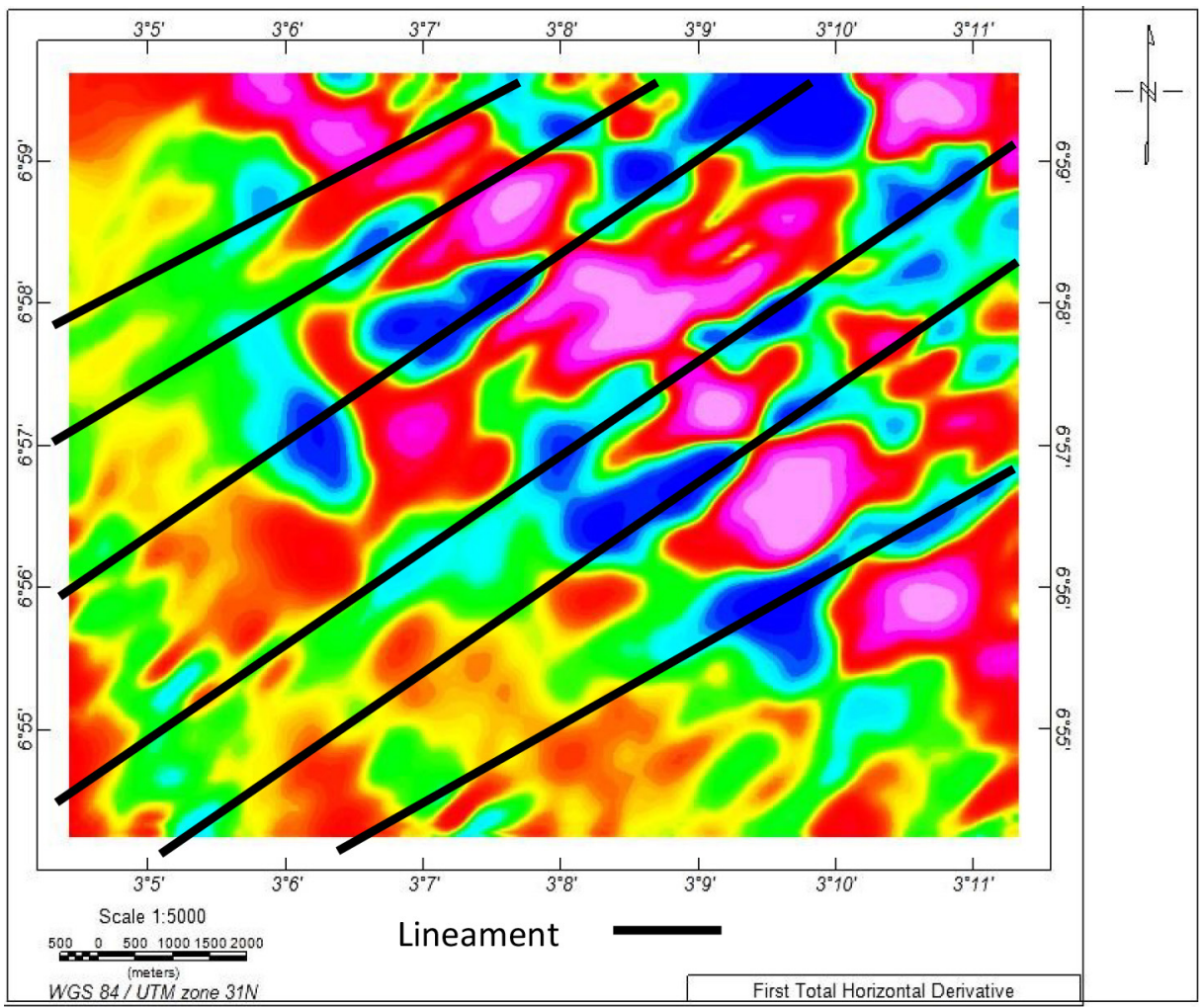

Figure 4: First horizontal derivative of residual map showing the mapped linear structure.

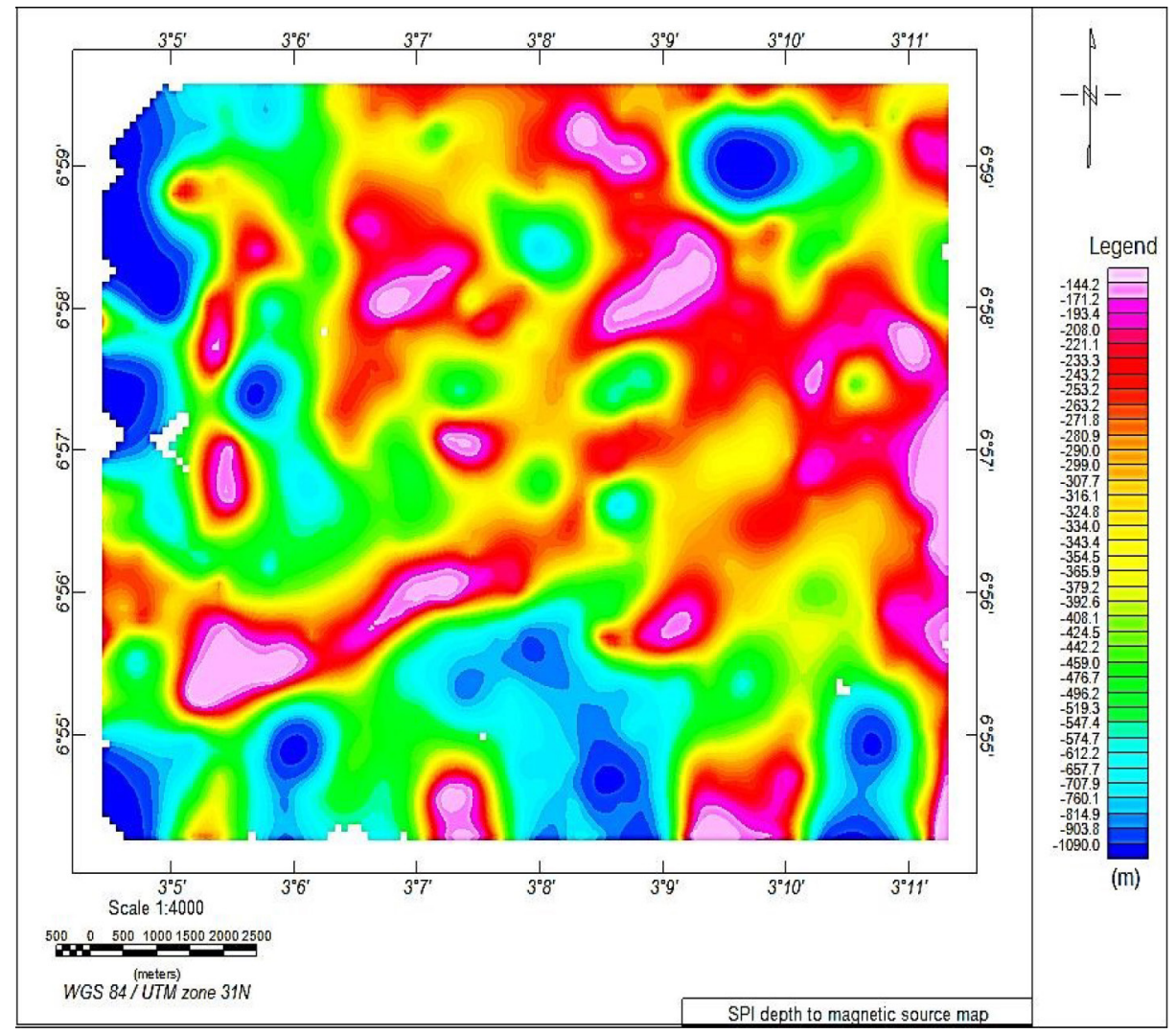

Figure 5: Source Parameter Imaging (SPI) showing depth to magnetic basement. 
Depth (m)

NW 0
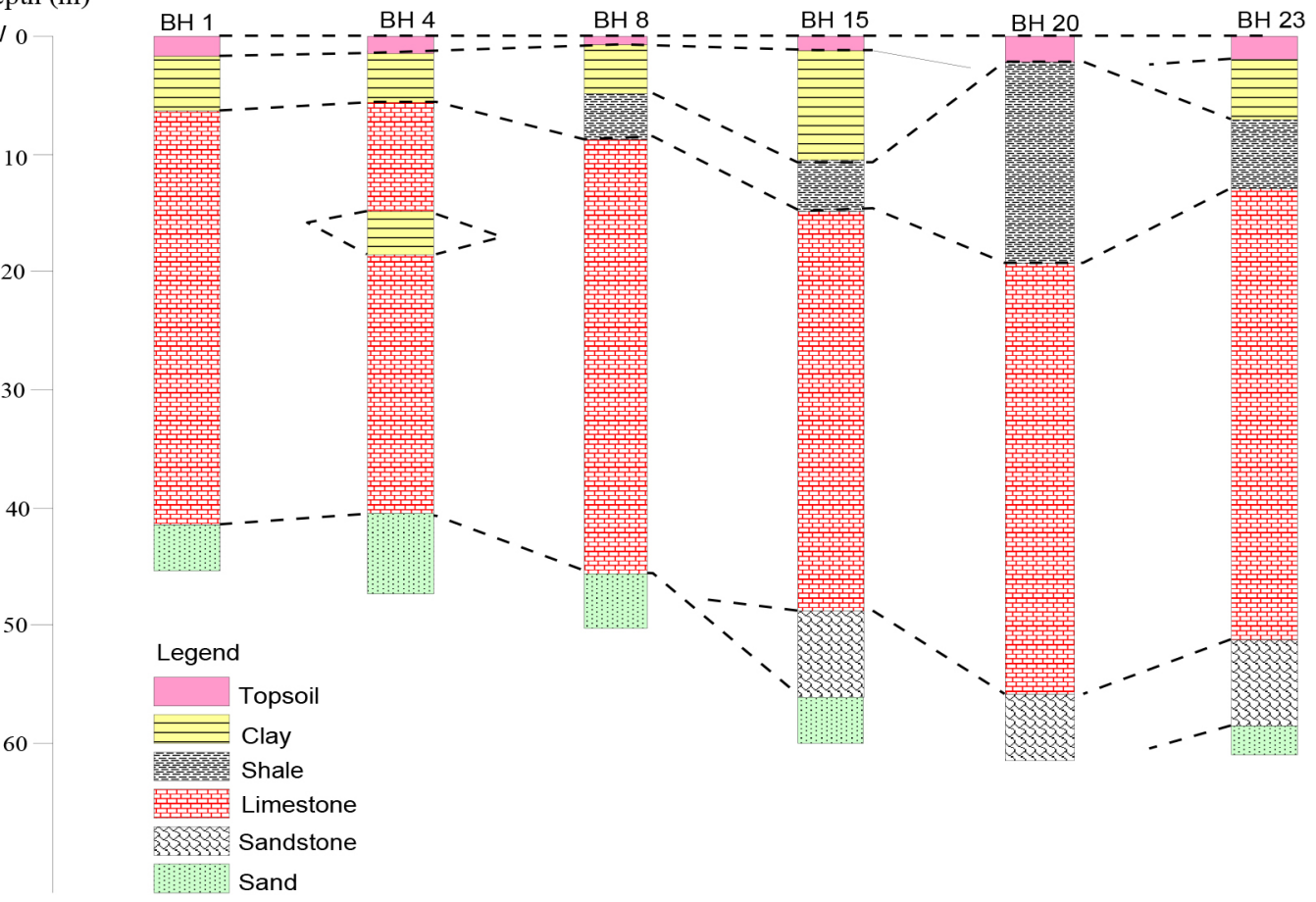

Figure 6a: NW-SE Borehole section

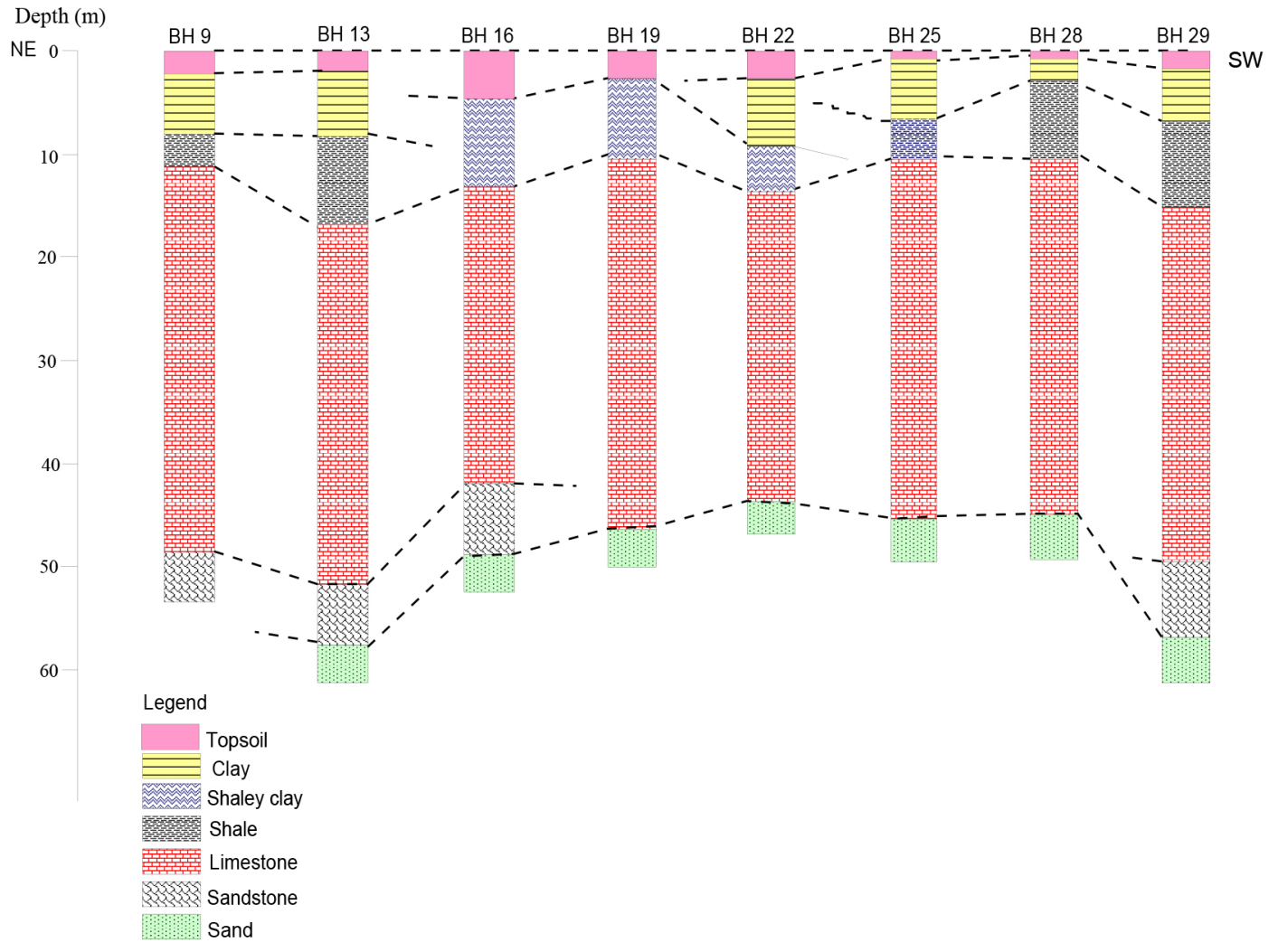

Figure 6b: NE-SW Borehole section 

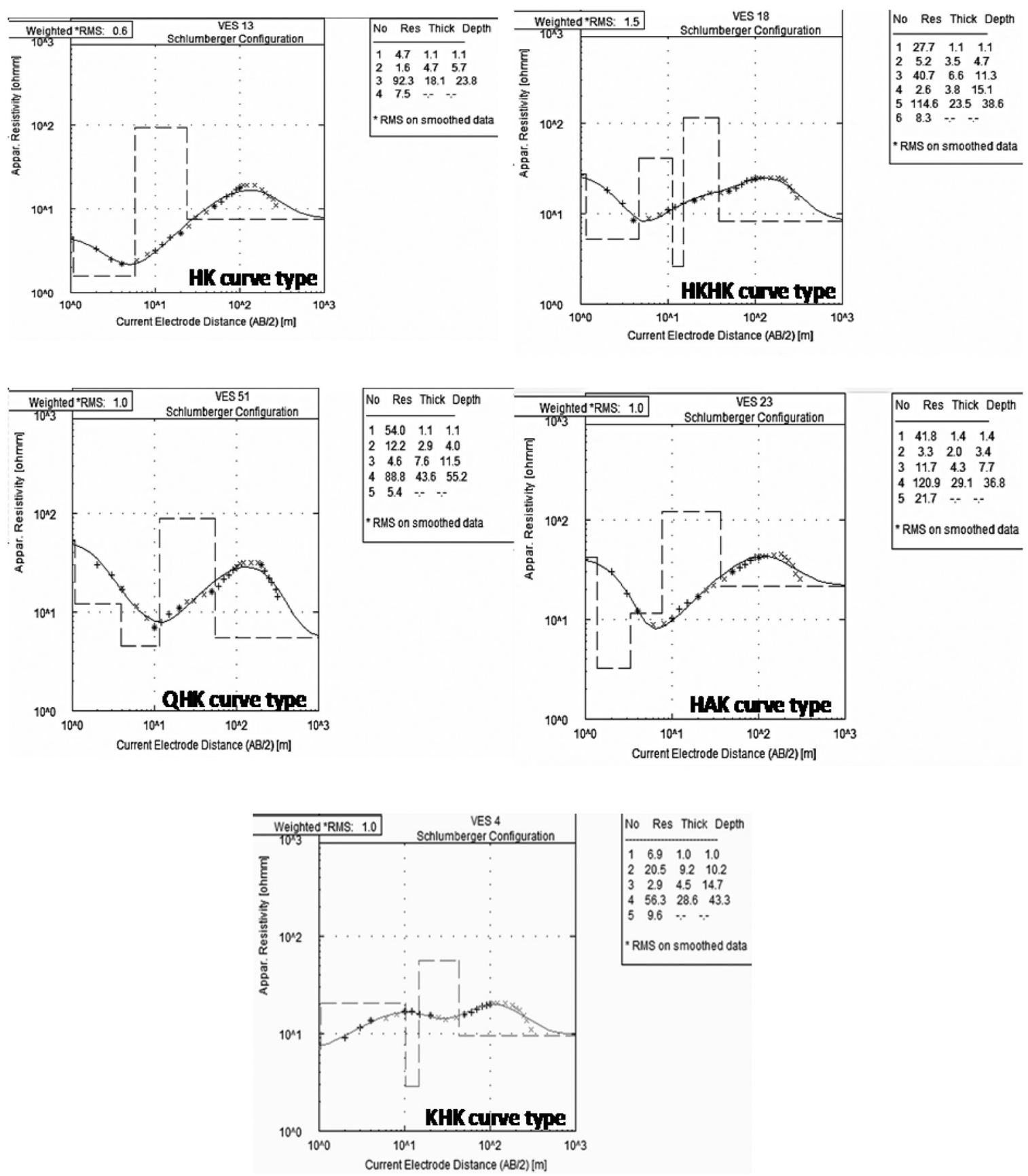

Figure 7: Typical VES type curves

\section{Geoelectric layers}

The VES results were grouped into HK, HAK, KHK, QHK and HKHK curve types (Figure 7) depicting 4-6 geoelectric layers. The HAK curve type is the most dominant (Figure 8). A maximum of six subsurface layers were identified beneath these sections and include the top soil, clay, shale clay, shale, limestone, sandstone and sand layer.

\section{Geoelectric Section along East-West direction}

Four to six subsurface layers were identified beneath this section, namely, topsoil, clay, shale, limestone, sandstone and sand (Figure 9a). The top soil had a resistivity value varying between 11-149 $\Omega \mathrm{m}$ with the thickness ranging from $0.7-1.40 \mathrm{~m}$. The thickness of the second layer (clay) ranged between 2.5 and $23.3 \mathrm{~m}$ with re- 


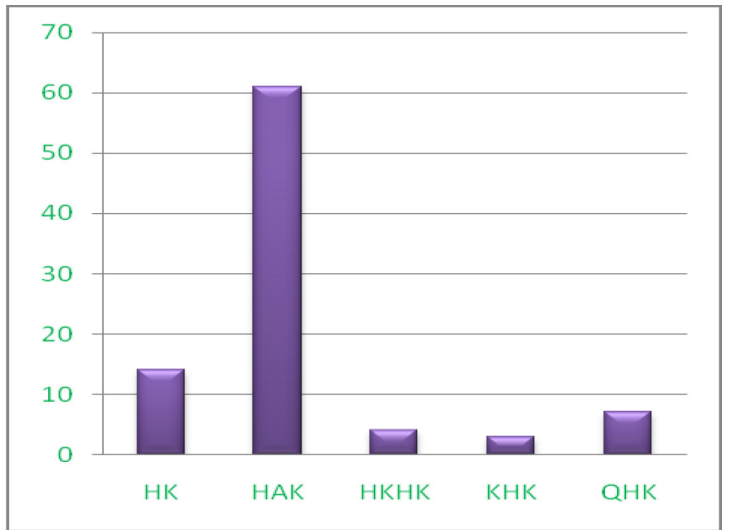

Figure 8: Histogram representation of curves types

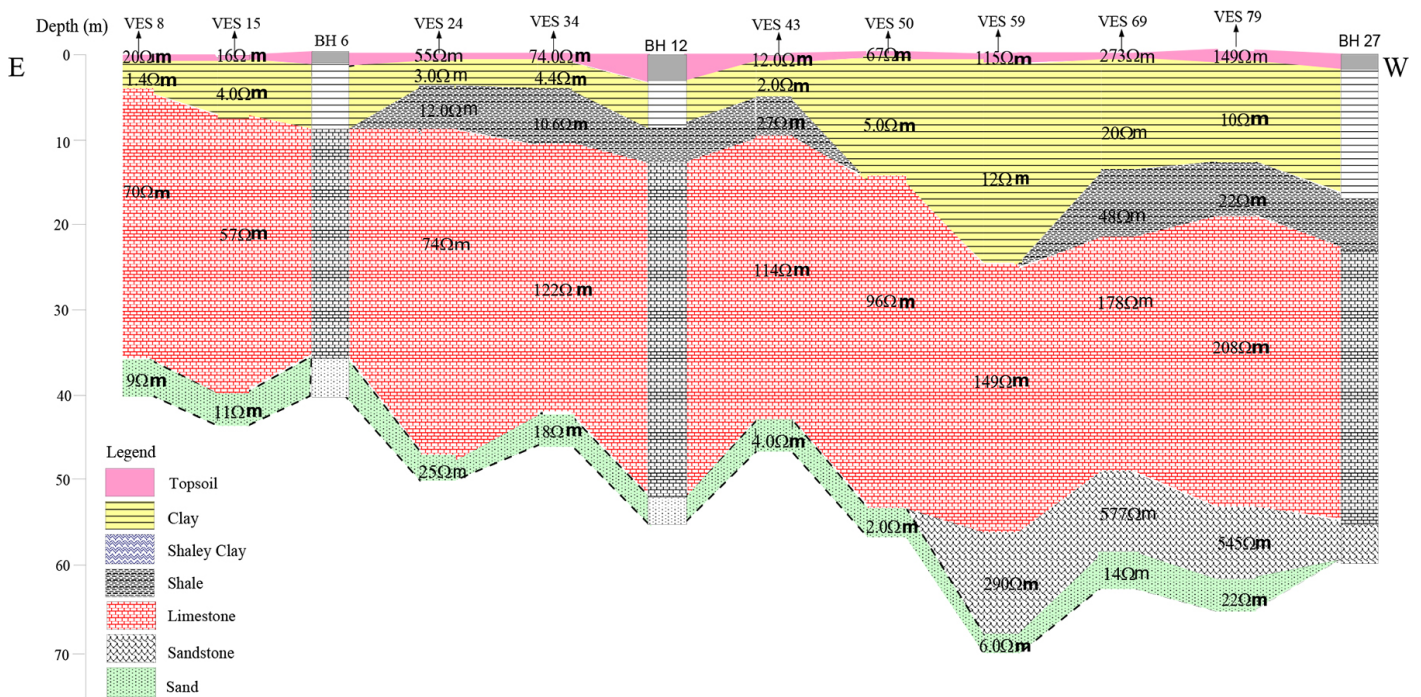

Figure 9a: Geoelectric Section along E-W direction.

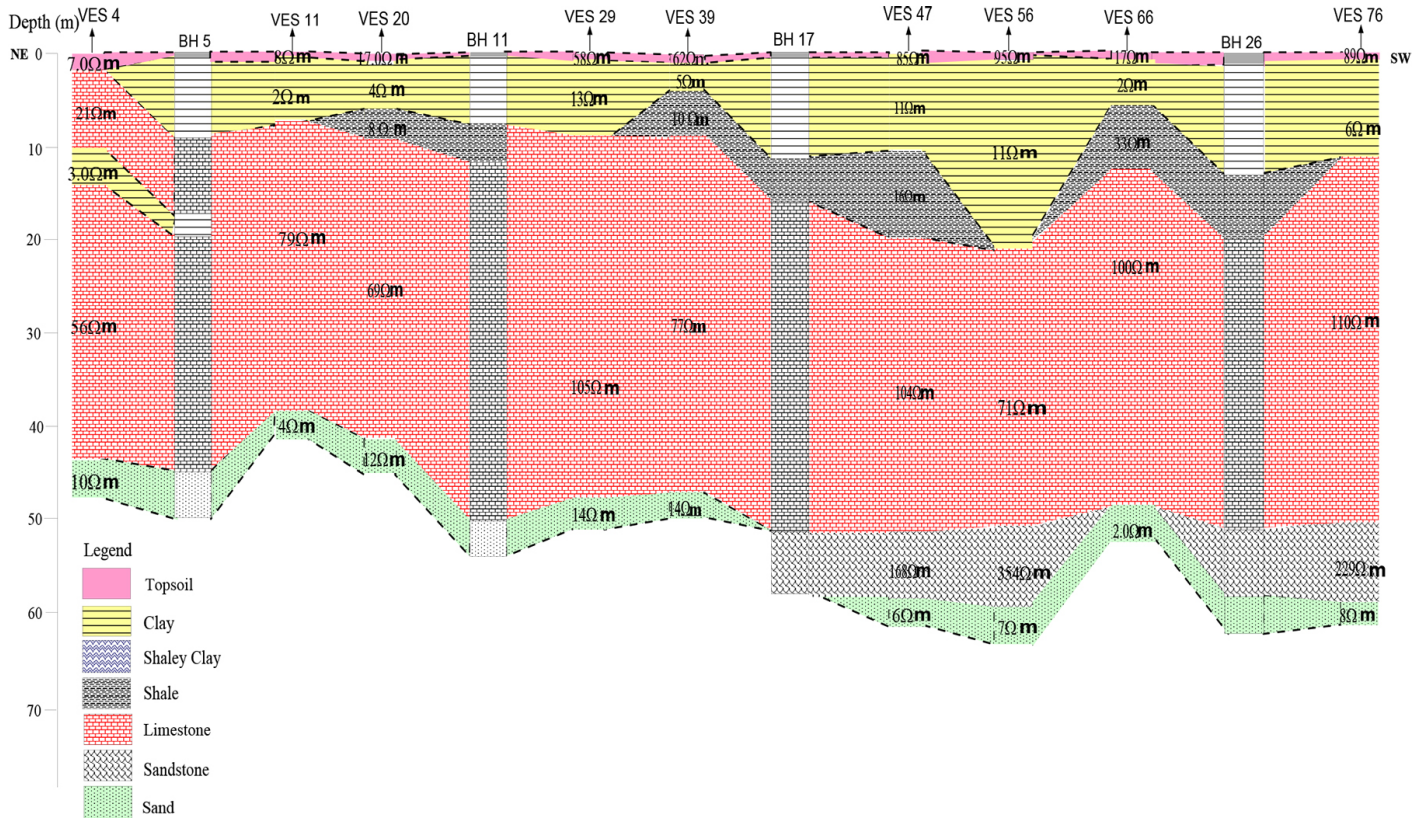

Figure 9b: Geoelectric Section along NE-SW direction. 


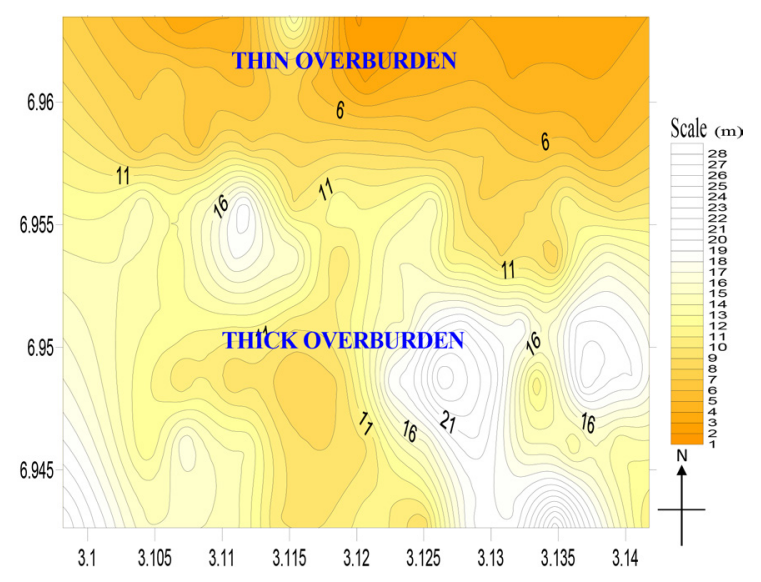

Figure 10: Map showing Overburden thickness

sistivity value between $1-20 \Omega \mathrm{m}$. VES 24 , VES 34, VES 43, VES 69 and VES 79 have a shale unit as the third layer with the thickness varying from 4.7-7.14 m. Limestone is the fourth layer having resistivity values ranging from 57$208 \Omega \mathrm{m}$ and thickness ranging between $28 \mathrm{~m}$ and $40 \mathrm{~m}$. Variation in the limestone resistivity values may be due to variation in degree of water saturation within the limestone deposits, or potentially due to tectonic deformation. The limestone slightly dips to the west beneath this section (Figure 9a). Sandstone (290-577 $\Omega \mathrm{m}$ ) was delineated beneath the locations of VES 59, 69 and $79 \mathrm{~m}$ with thickness between $8.4 \mathrm{~m}$ and $11.9 \mathrm{~m}$. The last layer was inferred to be sandy material (11-40 $\Omega \mathrm{m})$.

\section{Geoelectric Section along Northeast- Southwest direction}

Four to six subsurface layers were defined beneath this section (Figure 9b). The first layer is the topsoil with resistivity values that range from 7-95 $\Omega \mathrm{m}$ with thickness that varies between $0.7-3.30 \mathrm{~m}$. The thickness of the second layer varies between 3.5 and 18.1 m interpreted to be clay $(2-13 \Omega \mathrm{m})$. The third layer defined beneath VES 20,39, 47, and 66 was interpreted to be the shale layer $(10-33 \Omega \mathrm{m})$ with thickness values varying from $2.6-7.3 \mathrm{~m}$. The limestone unit has resistivity values varying from 69-110 $\Omega \mathrm{m}$ with thickness between $23.1 \mathrm{~m}$ and $35.9 \mathrm{~m}$. This correlated with BH 11, 17 and 26 . Depth to the top of the limestone generally increased from northeast to southwest. Below the limestone VES 47, 56 and 76 has resistivity values between $168-354 \Omega \mathrm{m}$ interpreted as

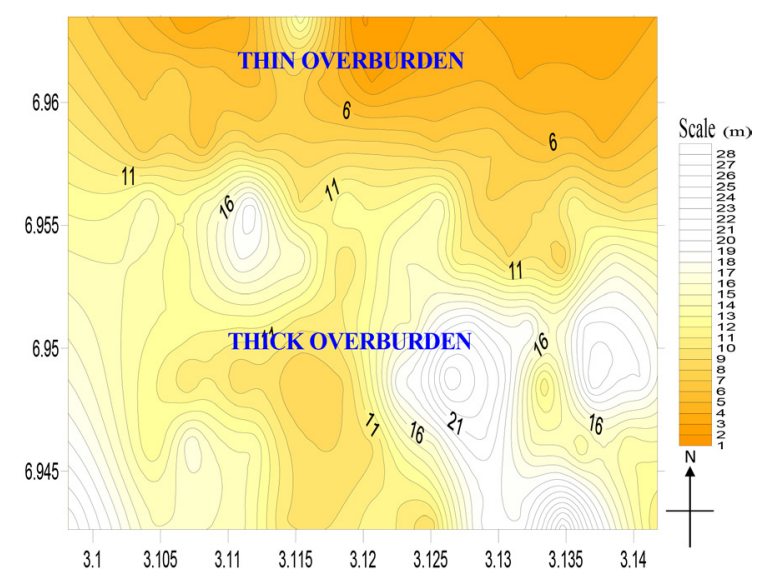

Figure 11: Map of Limestone thickness

sandstone with thickness $7.6 \mathrm{~m}$ to $12.1 \mathrm{~m}$, as observed in BH 17 and BH 26. The last layer at each VES station was inferred to be sandy material $(10-20 \Omega \mathrm{m})$.

\section{Limestone Reserve Estimation}

The study area has a dimension of $6.5 \mathrm{~km}$ by $3.7 \mathrm{~km}$, i.e. $24.05 \mathrm{~km}^{2}$; average thickness of limestone occurrence is estimated to be $32.7 \mathrm{~m}$ and limestone density is $2.5 \mathrm{~g} / \mathrm{m}^{3}$ [16].

Reserve Estimate $=$ Area $\mathrm{x}$ Thickness $\mathrm{x}$ Density $24,050,000 \mathrm{~m}^{2} \times 32.7 \mathrm{~m} \mathrm{x} 2.5 \mathrm{~g} / \mathrm{m}^{3} \approx 1.9 \times 10^{9} \mathrm{t}$.

\section{Limestone and Overburden Thickness}

Using the VES and borehole data, the overburden thickness was estimated at each data point. Values were interpolated and gridded using minimum curvature method over the investigated area to represent the Limestone overburden thickness map (Figure 10). The thickness of overburden ranged from $3.3 \mathrm{~m}$ to $28.0 \mathrm{~m}$. The contour map showed region of thick overburden (>11 m) in the southern part of the area, while the northern region was characterized by thin overburden $(<11 \mathrm{~m})$. Limestone could be easily encountered at shallow depth and economically exploited in regions of thin overburden along the northern part of the area. The limestone thickness map (Figure 11) showed variation in thickness around the study area. Regions of large limestone thicknesses ( $>30 \mathrm{~m}$ ) were elongated along NE-SW to N-S running corridors. 


\section{Conclusion}

This study investigated the Onigbedu limestone occurrence using combined aeromagnetic data, resistivity soundings and borings. The results obtained in this study provided information on the geological structure of the study area with the lineaments oriented in NE-SW direction. Depth to magnetic basement ranged from $144 \mathrm{~m}$ to $1090 \mathrm{~m}$. Strips of thick limestone ( $>30 \mathrm{~m}$ ) elongated in NE-SW to N-S direction were delineated. The reserve of the limestone in Onigbedu area was estimated at approximately $1.9 \times 10^{9} \mathrm{t}$ with overburden thickness that ranged from $3.3 \mathrm{~m}$ to $28.0 \mathrm{~m}$. This study has established that the investigated area (Onigbedu) is rich in limestone deposit which could be economically exploited.

\section{References}

[1] Omatsola, M.E. and Adegoke, O.S. (1981): Tectonic evolution and stratigraphy of the Dahomey basin. Journal of Mining and Geology, 18(1), pp. 130-137.

[2] William, L. (1997): Fundamental of Geophysics, Cambridge University Press, 206-217.

[3] Bell, J. P (1963): A Summary of the Principal Limestone and Marble Deposits of Nigeria. Geological Survey of Nigeria, Rep. 1192.

[4] Adegoke, O.S, Dessauvagie, T.F. J, Kogbe, C. A, Ogbe F.G.A (1971): Type section, Ewekoro Formation, biostratigraphy and microfacies, 4th African Micropal. Coll. Abidjan (1970), pp. 37-39.

[5] Ford, D.C.; Williams, P.W. (2007): Karst Geomorphology and Hydrogeology, 2nd ed.; John Wiley and Sons: Chichester, UK, 2007.

[6] Vouillamoz, J.M., Legchenko, A., Albouy, Y., Bakalowicz, M., Baltassat, J.M., AlFares, W. (2003): Localization of saturated karst aquifer with magnetic resonance sounding and resistivity imagery, Ground Water, 41(5), pp. 578-586.
[7] Van Schoor, M. (2002): Detection of sinkholes using 2D electrical resistivity imaging, Journal of Applied Geophysics, 50, pp. 393-399.

[8] Zhou, W., Beck, B.F. and Stephenson, J.B. (2000): Reliability of dipole-dipole electrical resistivity tomography for defining depth to bedrock in covered karst terrains. Environmental Geology, 39, 760-766.

[9] Ehinola, O.A, Oluwajana, A. and Nwabueze, C.O. (2012): Geophysical mapping and reserve estimation of limestone deposit at Arimogija - Okeluse parts of South-western Nigeria. Research Journal in Engineering and Applied Sciences, 1(1), pp. 7-11.

[10] Idowu, O.A., Ajayi, O. and Martins, O. (1998): Occurrence of Groundwater in part of the Dahomey Basin, South-western Nigeria, J. min. geol., 35(2), pp. 229100.

[11] Martin, L. (1966): Manual of Magnetic Interpretation Toronto: Computer Applications and Systems Engineering.

[12] Cordell, L., and Grauch, V.J.S., (1985): Mapping basement magnetization zones from aeromagnetic data in the San Juan Basin, New Mexico, in Hinze, William J. (ed.), The Utility of Regional Gravity and Magnetic Anomaly Maps: Society of Exploration Geophysicists, Tulsa, Oklahoma, pp. 181-197.

[13] Thurston, J.B. and Smith, R.S. (1997): Automatic conversion of magnetic data to depth, dip, and susceptibility contrast using the SPITM methods: Geophysics, 62(3), pp. 8-7-813.

[14] Zohdy, A.A. R., (1985): The auxiliary point method of electrical sounding interpretation and its relationship to the Dar Zarrouk parameters. Geophys., 30, pp. 55-64.

[15] Oldenburg, D.W. and Brune, J.N. (1975): An explanation to the orthogonality of ocean ridges and transform faults. J. Geophys. Res., 82, pp. 803-827.

[16] Kearey, P., Brooks, M. and Ian, H. (2002): An Introduction to Geophysical Exploration, (3rd ed.). Blackwell Science Limited, pp. 262. 
